\title{
FIRST PALYNOLOGIC RECORD OF THE CRETACEOUS LA YESERA FORMATION (SALTA GROUP), NORTHWESTERN ARGENTINA
}

\author{
PAULA LILIANA NARVÁEZ, MERCEDES BEATRIZ PRÁMPARO \\ Instituto Argentino de Nivología, Glaciología y Ciencias Ambientales (IANIGLA), CCT-CONICET, CC 330, 5500, \\ Mendoza, Argentina.pnarvaez@mendoza-conicet.gob.ar,mprampar@mendoza-conicet.gob.ar
}

IGNACIO FEDERICO SABINO

Tecpetrol S.A., Della Paolera 299, C1001ADA, Buenos Aires, Argentina. ignaciosabino@yahoo.com.ar

\begin{abstract}
Thirty-four taxa were documented from six palynologically productive samples of the La Yesera Formation (Brealito and Don Bartolo Members) in the Pucará locality (Salta Province, northwestern Argentina). In the Brealito Member, aquatic species (mainly freshwater algae) dominate the palynoflora, while terrestrial species are represented by trilete spores (mainly Anemiaceae) and gymnosperm pollen grains. In the Don Bartolo Member, Classopollis spp. dominate most of the assemblages, trilete Anemiaceae spores constitute half of the total counts in one of the assemblages and a unique angiosperm species (Tricolpites variabilis) was found in two assemblages. Ephedra-type pollen grains (three genera and six species) appear in both members, although in low abundance. The results support previous sedimentology studies that indicate a perennial lake environment at the time of deposition of the Brealito Member, with evidence for dry seasonality in the Don Bartolo Member. The inferred regional paleoclimate is subtropical with arid conditions. Considering the stratigraphic ranges of selected species and the sedimentology data, an Albian/Cenomanian age is suggested for the unit.
\end{abstract}

Key words: Palynology, Cretaceous, La Yesera Formation, northwestern Argentina.

RESUMO - Trinta e quatro táxons foram registrados a partir de seis amostras palinológicas provenientes da Formação La Yesera (membros Brealito e Don Bartolo), na localidade Pucará, Província de Salta, noroeste da Argentina. No Membro Brealito, predominam as espécies aquáticas, principalmente de algas de água doce; as espécies terrestres estão representadas por esporos triletes, principalmente de Anemiaceae e por grãos de pólen de gimnospermas. No Membro Don Bartolo, os grãos de pólen Classopollis spp. dominam a maioria das assembleias, embora numa das amostras, metade das contagens totais é constituída por esporos triletes de Anemiaceae e, uma única espécie de angiospermas (Tricolpites variabilis) foi encontrada em duas assembleias. Grãos de pólen do tipo Ephedra, com três gêneros e seis espécies, aparecem em baixa abundância em ambos os membros. Estes resultados corroboram estudos sedimentológicos anteriores e indicam ambiente lacustre perene, no momento da deposição do Membro Brealito, com evidência de sazonalidade seca para a Membro Don Bartolo. O paleoclima regional inferido é subtropical árido. Considerando os intervalos estratigráficos de espécies selecionadas e os dados sedimentológicos, é sugerida idade Albiano/Cenomaniano para a unidade estudada.

Palavras-chave: Palinologia, Cretáceo, Formação La Yesera, noroeste da Argentina.

\section{INTRODUCTION}

The tectonic evolution of southern South America has been influenced by a subduction regime in the western margin since the Mesozoic (Uliana \& Biddle, 1988). During the Early Cretaceous, extensional ruptures along the mid-Atlantic spreading system propagated northward from southern Argentina to southern Brazil and southwest Africa, giving rise to a narrow, wedge-shaped ocean basin (Rabinowitz \& LaBrecque, 1979). As a consequence, numerous rift basins originated in central and northwestern Argentina (Uliana et al., 1989), among them the Salta Group Basin.

The Salta Group includes three subgroups with three formations each: Pirgua (La Yesera, Las Curtiembres, and Los Blanquitos Formations), Balbuena (Lecho, Yacoraite, and
Olmedo/Tunal Formations), and Santa Bárbara (Mealla, Maíz Gordo, and Lumbrera Formations). The deposits range from the Early Cretaceous through the Eocene, and are located in seven sub-basins: Tres Cruces, Lomas de Olmedo, Metán, Alemanía, El Rey, Sey, and Brealito (Marquillas et al., 2005) (Figure 1A). Salfity \& Marquillas (1994) mention synrift and postrift deposits infilling the basin. The Pirgua Subgroup represents the synrift stage when faults were active, and the Balbuena and Santa Bárbara subgroups represent the postrift stage, when thermal subsidence occurred.

The basal unit of the Pirgua Subgroup, La Yesera Formation, was defined in the Alemanía sub-basin (Reyes \& Salfity, 1973) where it is mainly comprised of red beds. The deposits have a north-south orientation in the Brealito sub-basin, from the Olacapato ranges in Jujuy Province to the 
Brealito lake in southwestern Salta Province (Sabino, 2002). They are connected to the Miraflores Formation in Bolivia, where a Cenomanian marine ingression has been recorded (Sempere, 1995). The depositional environment consists of debris-flow dominated by alluvial fans to braided rivers in the lower section, mud plains to sandy braided rivers in the middle, and debris-flow dominated alluvial fans in the upper section (Marquillas et al., 2005). In the southern part of the basin, the sedimentation of the La Yesera Formation began at the same time as the Alto de Las Salinas Complex volcanic event, from which basalt and rhyolites were dated to 128$112 \mathrm{Ma}(\mathrm{K} / \mathrm{Ar}$, total rock; Bossi \& Wampler, 1969). Isonza Basalt effusions in the top of the formation were dated from $99 \pm 5$ to $96 \pm 5 \mathrm{Ma}$ (K/Ar total rock; Valencio et al., 1976). Hence, the accumulation of deposits spans the Barremian to the Cenomanian.

Fossil records from the La Yesera Formation are scarce: plant remains, algae, and undifferentiated ostracods were found in the top levels (Brealito sub-basin; Boso et al., 1984). Few palynologic studies have been published from the Pirgua Subgroup. Quattrocchio et al. (2005) reported CampanianMaastrichtian palynoflora from the passage beds between the Los Blanquitos and Lecho Formations in the Vilches locality (in the transition between the Alemanía and Metán sub-basins; Figure 1A), with typical Mesozoic taxa, in conjunction with angiosperm pollen grains. These grains have been recorded in younger sediments from lower latitudes of tropical South America and Africa, suggesting a northward migration of the taxa. Narváez \& Sabino (2008) provided the first palynologic record of the Morales Member of the Las Curtiembres Formation at El Chorro creek (Alemanía sub-basin, Figure 1A), with a prevalence of Ephedra-type pollen that suggests semiarid conditions, a warm-dry climate, and an age no older than Campanian, based on the presence of Peninsulapollis gilli (Cookson) Dettmann \& Jarzen 1988.

Based on the palynoflora, the authors aim to describe the paleoenvironmental context present at the time of deposition of the La Yesera Formation. These data are phytogeographically significant because of their geographical position (northern Argentina), a transition zone between equatorial and austral regions, and because most of the mid-Cretaceous palynologic reports in Argentina are from Patagonia (e.g. Archangelsky et al., 1983, 1994, 2008; Baldoni et al., 2001; Archangelsky \& Llorens, 2005, 2009; Medina et al., 2008; Perez Loinaze et al., 2012); or to a lesser extent, the central-western part of the country (Prámparo, 1989a,b, 1990, 1994; Prámparo \& Milana, 1999; Prámparo et al., 2005). Hence, our main objective is to contribute to the knowledge of mid-Cretaceous subtropical plant communities in South America $\left(\sim 25^{\circ} \mathrm{S}\right)$.

\section{Study area}

The palynologic samples reported here were collected in the Pucará valley (Figure 1B) within the Brealito subbasin, south-western Salta Province (Figure 1A). The Pirgua Subgroup in this sub-basin includes the La Yesera and Las Curtiembres Formations, approximately $2280 \mathrm{~m}$ and 900 $\mathrm{m}$ thick, respectively. The base of the La Yesera Formation is composed of sandstones and conglomerates (Yacutuy Member, $1000 \mathrm{~m}$ thick); the middle portion consists of pelites and scarce sandstones (Las Chacras Member, 660 $\mathrm{m}$ ) and an overlying pelitic section (Brealito Member, $290 \mathrm{~m}$ ); the top is composed of sandstones, pelites, and conglomerates (Don Bartolo Member, $330 \mathrm{~m}$ ) (Figure 2; Sabino, 2004). According to Sabino (2002), the Brealito Member deposits are related to a perennial lake, elongated in north-south direction that did not reach the Alemanía sub-basin (located $40 \mathrm{~km}$ eastward) (Figure 1A). The scarce distribution of deposits implies that flooding only occurred in areas of greater subsidence. Two stratigraphic sections were analysed in this study, which are from the upper levels of the La Yesera Formation and correspond to the Brealito and Don Bartolo Members (Figure 2).

\section{MATERIAL AND METHODS}

Fifteen rock samples were collected and processed for palynology from the upper stratigraphic sections (Figure 2) of the La Yesera Formation in the Pucará valley (Figure 1B). The physical and chemical extraction of palynomorphs was performed in the Paleopalynologic Laboratory at the Instituto Argentino de Nivología, Glaciología y Ciencias Ambientales (IANIGLA, Mendoza). Samples were treated with hydrochloric and hydrofluoric acids following standard techniques (Volkheimer \& Melendi, 1976). Residue was sieved with a $10 \mu \mathrm{m}$ nylon mesh-sieve.

Only six samples were palynologically productive, two of them from the top of the Brealito Member (laboratory catalogue numbers 8435-8436; Figures 2A-C), and four from the Don Bartolo Member (laboratory catalogue numbers 8446 , 8448-8450; Figure 2D). The slides were examined under a light microscope (Olympus BX50 with digital camera) for qualitative and quantitative assessment of palynomorphs. Specimens were located on the slide using an England Finder graticule. Palynologic analysis included systematic study, comparison of palynomorphs with modern families, and counts of 200-250 morphotypes. Palynomorph grains were described following Punt et al.'s (2007) terminology, and Dettmann's (1995) for megaspores. The slides are stored at the Paleopalynologic Collection at IANIGLA under the acronym MPLP (Mendoza-Paleopalinoteca-LaboratorioPaleopalinología).

\section{SYSTEMATIC PALYNOLOGY}

A total of 34 palynomorph species were identified (see Appendix for the taxonomic list). In this section are provide descriptions of the taxa with open assignations or with biostratigraphic or paleoenvironmental significance. Described species are included in the following botanical groups: bryophytes and pteridophytes, gymnosperm, angiosperm and algae (see Fensome, 1987 for discussion on methods for organizing fossil species). A complete revision and taxonomic discussion of the cicatricose species found in the La Yesera Formation is included in Narváez et al. (2013). 


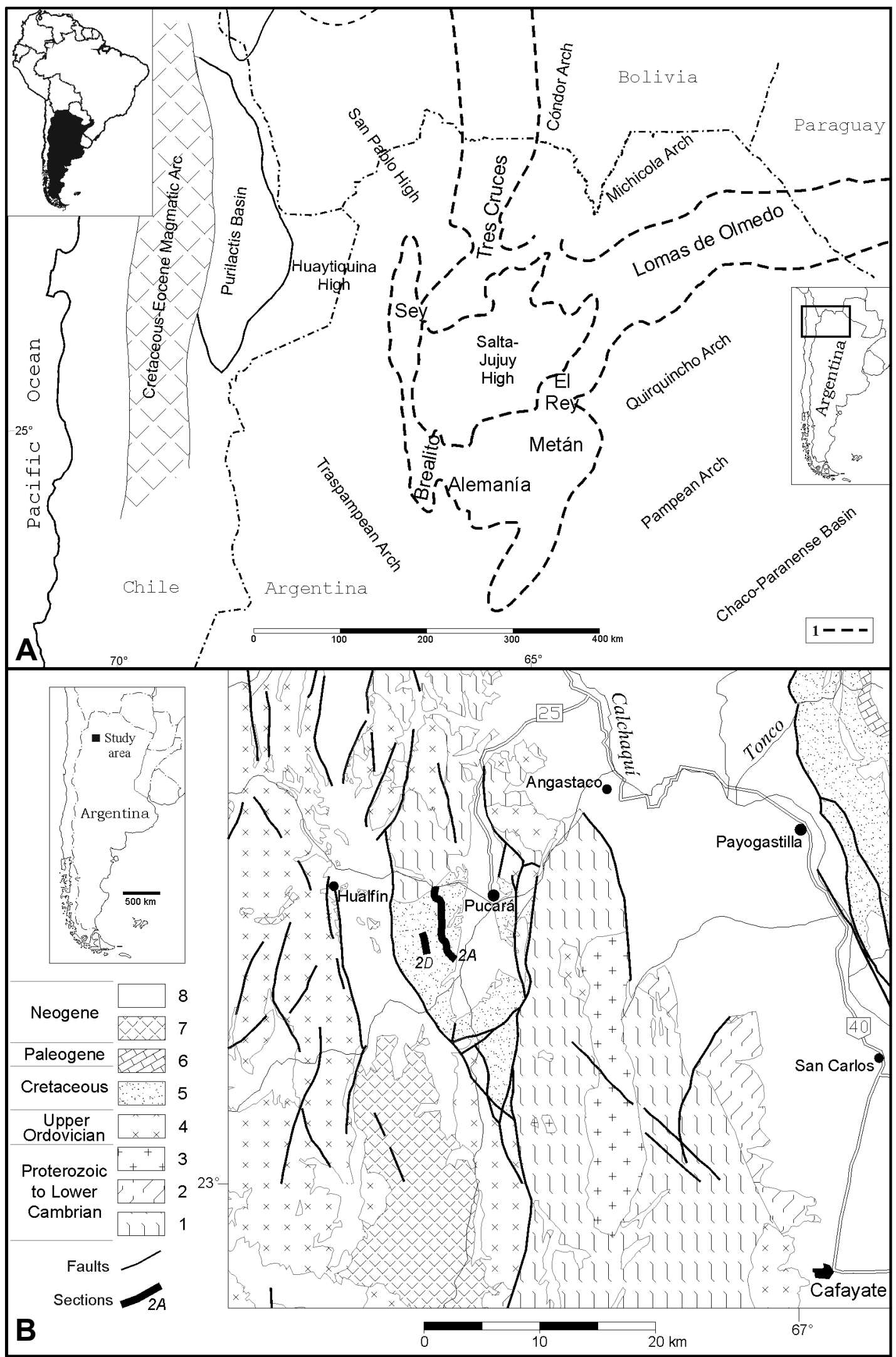

Figure 1. Location maps. A, Northwestern Argentina showing main structural highs and sub-basins present during the accumulation of the Pirgua Subgroup (Salta Group), 1. synrift stage basin margin. (from Sabino, 2002); B, sample locality: Pucará valley, 1. high-grade metamorphic rocks, 2. low-grade metamorphic rocks, 3. trondhjemite, granite and granodiorite, 4. granite and granodiorite, 5. red beds (Pirgua Subgroup), 6. continental marine deposits (Balbuena and Santa Bárbara subgroups), 7. volcanic rocks, 8. sediments. 


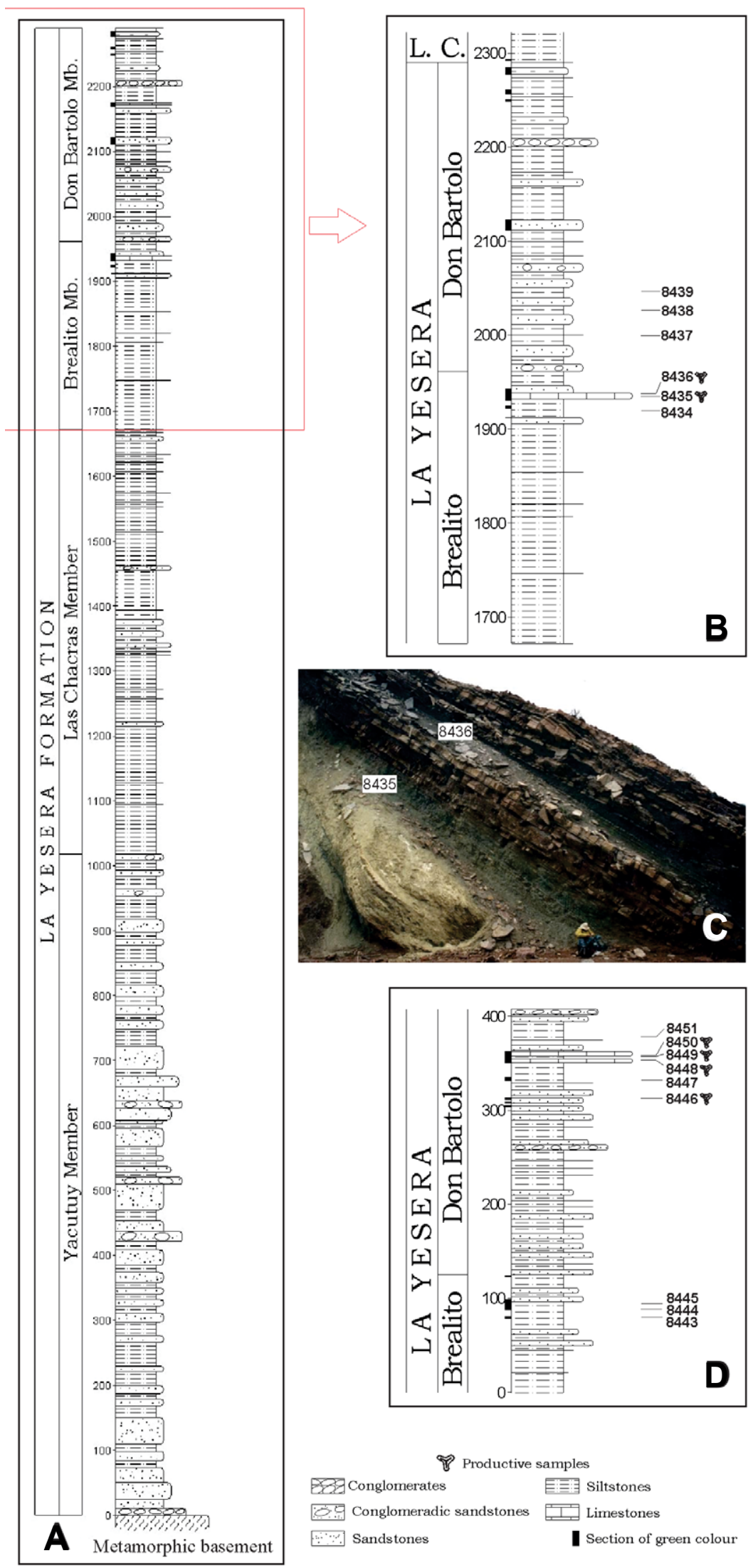

Figure 2. Stratigraphic logs of the La Yesera Formation in the Pucará valley (Brealito sub-basin). A, section 1; B, detailed upper portion of section 1 showing the location of palynologic samples; C, outcrop of the Brealito Member at the Pucará valley composed of yellow calcareous mudstone in the base and two coarsening-upward sequences of green shale and white sandstone. Productive samples (8435-8436) collected from the base of each sequence; D, section 2 showing the location of palynologic samples from the Don Bartolo Member. 


\section{Bryophytes and pteridophytes}

Balmeisporites (Cookson \& Dettmann) Dettmann, 1995

Type species. Balmeisporites holodictyus Cookson \& Dettmann, 1958a.

\section{Balmeisporites sp.1}

(Figures 3B-C)

Description. Trilete spores. Circular, oval to irregular equatorial amb. Laesura straight, rays reaching $3 / 4$ of the spore radius. Spherical exospore encapsulated by an irregular epispore, a pyramidal acrolamella extending 32-40 $\mu \mathrm{m}$ over the exospore in the proximal pole. Episporal surface formed by thin membranous projections (generally torn), closely disposed of 1.5-(3)-5 $\mu \mathrm{m}$ width and 3-(10)-15 $\mu \mathrm{m}$ high; slightly more prominent expansions in each equatorial radial region are observed in some specimens.

Dimensions. Diameter of spore body: 65-(92)-140 $\mu \mathrm{m}$; diameter including the epispore: 67-(124)-193 $\mu \mathrm{m}$ (17 specimens).

Comparison. Balmeisporites holodictyus has similar spore body size $(80-120 \mu \mathrm{m})$ and total dimensions including the epispore (equatorial: $120-160 \mu \mathrm{m}$; polar: $170-220 \mu \mathrm{m}$ ), but the acrolamella projection at proximal pole is much higher $(80-110 \mu \mathrm{m})$ and the episporal surface forms a distinct reticulum with circular to polygonal lumina (Cookson \& Dettmann, 1958a; Dettmann, 1995). B. glenelgensis Cookson \& Dettmann, 1958a is similar to $B$. holodictyus but with a larger spore body $(107-135 \mu \mathrm{m})$ and shallower and closer mesh. B. tridictyus Cookson \& Dettmann, 1958a (spore body size $80-115 \mu \mathrm{m}$ ) lacks the reticulate sculpturing and the acrolamella is composed of three leaflike segments, which are ordered symmetrically around the proximal pole and united at their edge, enclosing the tetrad scar.

Remarks. The genus has botanical affinity to Salviniaceae according to Villar de Seoane \& Archangeslky (2008).

\section{Ceratosporites Cookson \& Dettmann, 1958b}

Type species. Ceratosporites equalis Cookson \& Dettmann, 1958 b.

\section{?Ceratosporites $\mathrm{sp}$.}

(Figure 3E)

Description. Trilete spore. Subcircular amb. Laesura not visible. Exine $0.5 \mu \mathrm{m}$ thick. Surface ornamented with bacula 2-4 $\mu \mathrm{m}$ high and 1-1.5 $\mu \mathrm{m}$ diameter at the base, with capitate extremes occasionally bifurcate, distributed along the muri of a reticulum with 2-3 $\mu \mathrm{m}$ lumina or depressions.

Dimensions. Equatorial diameter: $40 \mu \mathrm{m}$ (1 specimen).

Remarks. The unique specimen is assigned with doubt to Ceratosporites as it has an undistinguished laesura and a probable ornamented proximal face.
Comparison. Ceratosporites equalis has a prominent and distinct laesura reaching equator and a smooth proximal face (Cookson \& Dettmann, 1958b). The ornamentation in the distal face of the extant species Anthoceros multifidus Lindb. (Anthocerotophyta, Bryophyte) is very similar to our specimen (see SEM photographs in Warny et al., 2012), indicating a probable botanical affinity.

\section{Cristatitriletes Mädler, 1964}

Type species. Cristatitriletes baculatus Mädler, 1964.

\section{?Cristatitriletes $\mathrm{sp}$.}

(Figure $3 \mathrm{H}$ )

Description. Trilete spore. Oval amb. Laesura straight, rays reaching $3 / 4$ of the spore radius. Exine $0.5 \mu \mathrm{m}$ thick. Surface ornamented with bacula and spines, $2-5 \mu \mathrm{m}$ high and 1-1.5 $\mu \mathrm{m}$ diameter at the base, generally with bifurcated tips, irregularly and densely distributed around surface. Some of the elements fuse at their bases forming irregular crests, more distinct around equator.

Dimensions. Equatorial diameter: $56 \mu \mathrm{m}$ (1 specimen).

Remarks. Although the genus Cristatitriletes includes spores with cristae that consist of fused or coalescing baculae coincident with our specimen, the unique species $C$. baculatus has been recorded in Late Permian and Triassic sediments (Traverse \& Ames, 1968; Jansonius \& Hills, 1976; Eshet, 1990).

Comparison. Cristatitriletes baculatus is larger $(c a .75 \mu \mathrm{m})$ and the cristae form a reticulate equatorial and distal pattern (Jansonius \& Hills, 1976).

\section{Matonisporites Couper, 1958}

Type species. Matonisporites phlebopteroides Couper, 1958.

?Matonisporites $\mathrm{sp}$.

(Figures 3N-O)

Description. Trilete spores. Subtriangular amb with straight to slightly convex sides and rounded angles. Laesura straight, rays reaching $2 / 3$ to $3 / 4$ of the spore radius, margo $8-(11)-20$ $\mu \mathrm{m}$ width at each side of the laesura. Crassitude around equator in proximal face 7-(13)-20 $\mu \mathrm{m}$ width. Exine 2-3 $\mu \mathrm{m}$ thick, thicker around equator: 5-7 $\mu \mathrm{m}$, laevigate to scabrate, generally corroded.

Dimensions. Equatorial diameter: 95.5-(118)-155 $\mu \mathrm{m}(10$ specimens).

Remarks. The large size is the notorious characteristic of these spores. The genus Matonisporites was originally created to include large spores with triangular amb, laesura with margo, and laevigate thick exine (Couper, 1958). Dettmann (1963) emended the original diagnosis, restricting the genus to smooth valvate trilete spores (i.e. thicker exine in equatorial radial regions). The authors could not differentiate the presence of true valvae in our specimens, so they prefer to assign them with doubt to Matonisporites. 
Comparison. Matonisporites equiexinus Couper, 1958 is smaller (40-(58)-68 $\mu \mathrm{m})$ and has thinner exine $(2.5-3,5 \mu \mathrm{m})$. M. sp. A (see figure 14.T, page 24 in Helby et al., 1987) has an exine of approximately $4 \mu \mathrm{m}$ thick but there is no description of the illustrated specimen.

Raistrickia Schopf, Wilson \& Bentall, 1944

Type species. Raistrickia grovensis Schopf, Wilson \& Bentall, 1944.

\section{?Raistrickia $\mathrm{sp}$}

(Figure 3Q)

Description. Trilete spore. Oval amb. Laesura hardly distinct, straight. Exine 1.5-2 $\mu \mathrm{m}$ thick. Surface ornamented with bacula, $1.5 \mu \mathrm{m}$ diameter at the base and 5-5.5 $\mu \mathrm{m}$ high, with tips dissected into several papillae, irregularly and densely distributed over the whole surface, 1-4 $\mu \mathrm{m}$ apart.

Dimensions. Equatorial diameter: $63 \mu \mathrm{m}$ (1 specimen).

Remarks. The specimen is not confidently assigned to Raistrickia as this genus has been previously recorded in Upper Paleozoic-Lower Mesozoic sediments of Argentina (e.g. Azcuy, 1975; Zavattieri, 1992; García, 1995).

Comparison. Raistrickia sp. A (García, 1995) is similar in size $(72 \mu \mathrm{m})$, but with larger bacula $(3.5-5.8 \mu \mathrm{m}$ wide and 7-9 $\mu \mathrm{m}$ high).

\section{Gymnosperm}

Ephedripites Bolkhovitina ex Potonié, 1958

Type species. Ephedripites mediolobatus Bolkhovitina ex Potonié, 1958.

Ephedripites ovatus (Pierce) comb. nov.

(Figures 4H-I)

Basyonim. Striainaperturites ovatus Pierce, 1961. Minnesota Geological Survey Bulletin.

42 , p. 45 , plate 3 , fig. 80 ; holotype $29 \mathrm{H}-4$ 33.9/123.7, plate 3, fig. 80 .

Synonym. Equisetosporites ovatus (Pierce) Singh, 1964.

Description. Polyplicate pollen grains. Oval outline with acute to rounded extremities. Exine $0.5 \mu \mathrm{m}$ thick, sculptured with 8-12 straight and flat ridges running parallel to the longitudinal axis, each ridge $2-5 \mu \mathrm{m}$ width in the central part and narrowing towards the longitudinal ends where they fuse in an area of 2-3 $\mu \mathrm{m}$ width. Furrows 0.3-0.5 $\mu \mathrm{m}$ wide.

Dimensions. Length: 29-(32)-36 $\mu \mathrm{m}$; maximum breath: 22(24)-27 $\mu \mathrm{m}$ (5 specimens).

Remarks. The authors make the new combination to the genus Ephedripites as they consider it is more indicative of its ephedralean affinity, also taking into account that this genus has been widely used as synonym of Equisetosporites.
Angiosperm

Tricolpites (Cookson ex Couper) Jarzen \& Dettmann, 1989

Type species. Tricolpites reticulatus (Cookson) Jarzen \& Dettmann, 1989.

Tricolpites variabilis Burger, 1970

(Figures 4Q-R)

Description. Tricolpate pollen grain, prolate. Colpi medium long, generally indistinct, sometimes costate. Exine 0.7-1 $\mu \mathrm{m}$ thick, semitectate, nexine $0.2-0.3 \mu \mathrm{m}$, sexine $0.5-0.7 \mu \mathrm{m}$. Reticulum formed by lumina of circular, oblong, or polygonal outline, slightly heterobrochate (0.4-0.7 $\mu \mathrm{m}$ diameter).

Dimensions. Polar length: 21-24 $\mu \mathrm{m}$; equatorial length: 17-18 $\mu \mathrm{m}$ (3 specimens).

Remarks. The specimens were found only in equatorial view.

Algae

Botryococcus Kützing, 1849

Type species. Botryococcus braunii Kützing, 1849

Botryococcus sp.

(Figures 5A-B)

Description. Compound rounded colonies, botryoidal, non branched. Lobules almost spherical, 11-33 $\mu \mathrm{m}$ in diameter, depending on the stage of development. Each lobule contains numerous cups (4-8 $\mu \mathrm{m}$ in diameter), tightly arranged, walls 1-1.5 $\mu \mathrm{m}$ thick. In some colonies, the cups are not clearly distinguished due to poor preservation.

Dimensions. 20-(65)-165 $\mu \mathrm{m}$ (40 colonies).

Remarks. The genus Botryococcus belongs to the Family Botryococcaceae within the Order Chlorococcales (Zippi, 1998).

\section{Algae incertae sedis}

Leiosphaeridia Eisenack emend Downie \& Sarjeant, 1963

Type species. Leiosphaeridia baltica Eisenack, 1958.

Remarks. The genus Leiosphaeridia has a polyphyletic origin and is an incertae sedis group that should be included in the acritarch subgroup "Sphaeromorphitae" (see discussion of the genus in Martínez et al., 2005).

\section{Leiosphaeridia-type 1}

(Figures 5C-D)

Description. Spheroidal vesicles, usually with folds. Thin wall of approximately $0.2 \mu \mathrm{m}$ thick, hyaline, laevigate.

Dimensions. Vesicle diameter: 32-(39)-46 $\mu \mathrm{m}$ (5 specimens). Comparison. The specimens studied have the same 
morphologic features as Leiosphaeridia hyalina (Deflandre) Downie, 1957.

\section{Leiosphaeridia-type 2}

(Figure 5E)

Description. Spheroidal vesicles, sometimes with folds. Thin wall of approximately $0.2 \mu \mathrm{m}$ thick, hyaline, ornamented with microgranules of less than $1 \mu \mathrm{m}$ in diameter, less than $1 \mu \mathrm{m}$ apart, irregularly distributed over the entire surface.

Dimensions. Vesicle diameter: $38-44 \mu \mathrm{m}$ (2 specimens).

Comparison. The specimens are similar to Leiosphaeridia sp. e described in Prámparo (1988, 1989b) for the Late Aptian La Cantera Formation (San Luis Basin).

\section{Echinate vesicle indet.}

(Figures 5F-G)

Description. Spheroidal vesicles, usually with folds. Thin wall of approximately $0.2 \mu \mathrm{m}$ thick, scabrate, densely covered with spines of 1-1.2 $\mu \mathrm{m}$ high, sometimes with bifurcated tip. Some specimens have an internal circular accumulation body of $4-5 \mu \mathrm{m}$ in diameter.

Dimensions. Vesicle diameter: 24.5-(32)-39 $\mu \mathrm{m} \mathrm{(5}$ specimens).

Comparison. Comasphaeridium sp., described from the Late Aptian La Cantera Formation (Prámparo, 1988b, 1989b), is very similar to these vesicles. The freshwater dinoflagellate cyst Protoellipsodinium fibratum (Batten \& Lister) Wan Chuanbiao et al., 1997 has similar morphological features (Batten \& Lister, 1988; Wan Chuanbiao et al., 1997). Nevertheless, our specimens do not show any kind of apertural structure.

\section{PALEOENVIRONMENTAL AND CLIMATIC CONSIDERATIONS}

The palynomorph assemblages of the La Yesera Formation (Pirgua Subgroup) constitute the oldest palynologic record of the Salta Group and one of the few from Cretaceous sediments in northwestern Argentina. Thirty-four species were recovered from the top levels of the Formation, from the Brealito and Don Bartolo Members outcropping in the Pucará locality (Figures 1,2). Counts of the different assemblages are summarized in Figure 6.

\section{Brealito Member}

The palynologic assemblages (8435-8436; Figures 2B-C) shows a prevalence of aquatic species (71-76\%; Figure 6). The chlorococcal algae Botryococcus sp. dominates the assemblage $8435(71 \%)$. These algae have been widely used as paleoenvironmental indicators, based on their colonies' stage of development, preservation, and resistance to variation in saline concentration (e.g. Guy-Ohlson, 1992, 1998; Batten \& Grenfell, 1996, Rodríguez Amenábar \& Ottone, 2003; Ottone et al., 2005; Ottone \& Mancuso, 2006; Zavattieri \& Prámparo, 2006). They commonly form water blooms in hard water lakes and ponds (Zippi, 1998). The colonies studied here had a wide size range (20-165 $\mu \mathrm{m})$ and different stages of development and preservation conditions, which suggest almost uniform environmental conditions.

Leiosphaeridia-type 1 dominates assemblage 8436 (70.8\%; Figure 6), while the circular vesicle densely ornamented with spines was scarce (Echinate vesicle indet., 4\%; Figures 5F-G). Although aquatic Leiosphaeridia forms have been generally associated with brackish or marine environments, Prámparo (1989b) reported their presence in the lacustrine Cretaceous La Cantera Formation (San Luis Basin) with a great variety of forms and high abundances $(80 \%)$, in association with freshwater algae such as Botryococcus, Scenedesmus, Tetrastrum, Tetraedron, and the same echinate vesicle recorded in the La Yesera Formation.

Pteridophyte species in both palynofloras were mostly represented by cicatricose spores of the Anemiaceae family ( 8.1 and $16.4 \%$, in assemblages 8435 and 8436 respectively) and only about $1 \%$ belonged to other taxa (e.g. Deltoidospora minor) (Figure 6). Gymnosperm pollen grains were more abundant and diverse in assemblage 8435 (12.5\%), including Balmeiopsis limbatus, Alisporites sp., Classopollis sp., Ephedra-type pollen, Cycadopites sp., and inaperturate grains; whereas in assemblage 8436, only B. limbatus and Ephedratype pollen $(4 \%)$ were present

Considering the palynological assemblages described here and the sedimentologic data provided by Sabino (2004), the inferred depositional environment for the sediments yielding assemblage 8435 is a shallow, perennial lake, represented mainly by marls and yellow limestones. For the sediments containing assemblage 8436, lacustrine conditions associated with deltaic facies are inferred. Pteridophyte species would have grown surrounding bodies of water where the aquatic forms developed, while gymnosperms would have grown in more elevated areas farther from the depositional site.

\section{Don Bartolo Member}

Unlike the Brealito Member, aquatic forms were scarce in the Don Bartolo Member assemblages (Figures 2D and 6). Classopollis pollen grains dominate the assemblages; making up almost three-quarters of the total from samples 8446 , 8448 and 8450 (Figure 6). Classopollis simplex was the most common, followed by $C$. classoides. These rimulated grains belong to the extinct Cheirolepidiaceae family of conifers, which may have been present in tropical to subtropical coastal environments (Vakrameev, 1981), although they have also been associated with fluvial and lake deposits, growing in well-drained soils. This family is associated with hot, arid, and seasonally dry climatic conditions (Herngreen \& Chlonova, 1982; Lima, 1983; Batten \& MacLennan, 1984).

Other gymnosperm include Cycadopites sp. (2.5-6.3\%) and Ephedra-type pollen (4.9-8.8\%) (Figure 6), with three genera and six species, present in all samples. Gnetales have been widely used as indicators of semiarid to arid environments based on comparison to their extant representatives (Srivastava, 1968). However, these interpretations have been questioned by Frederiksen (1985) and Archangelsky 

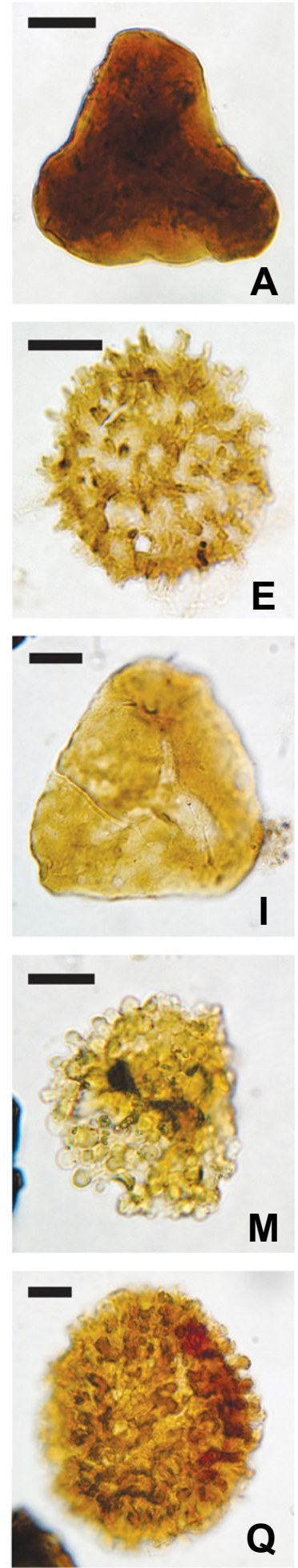
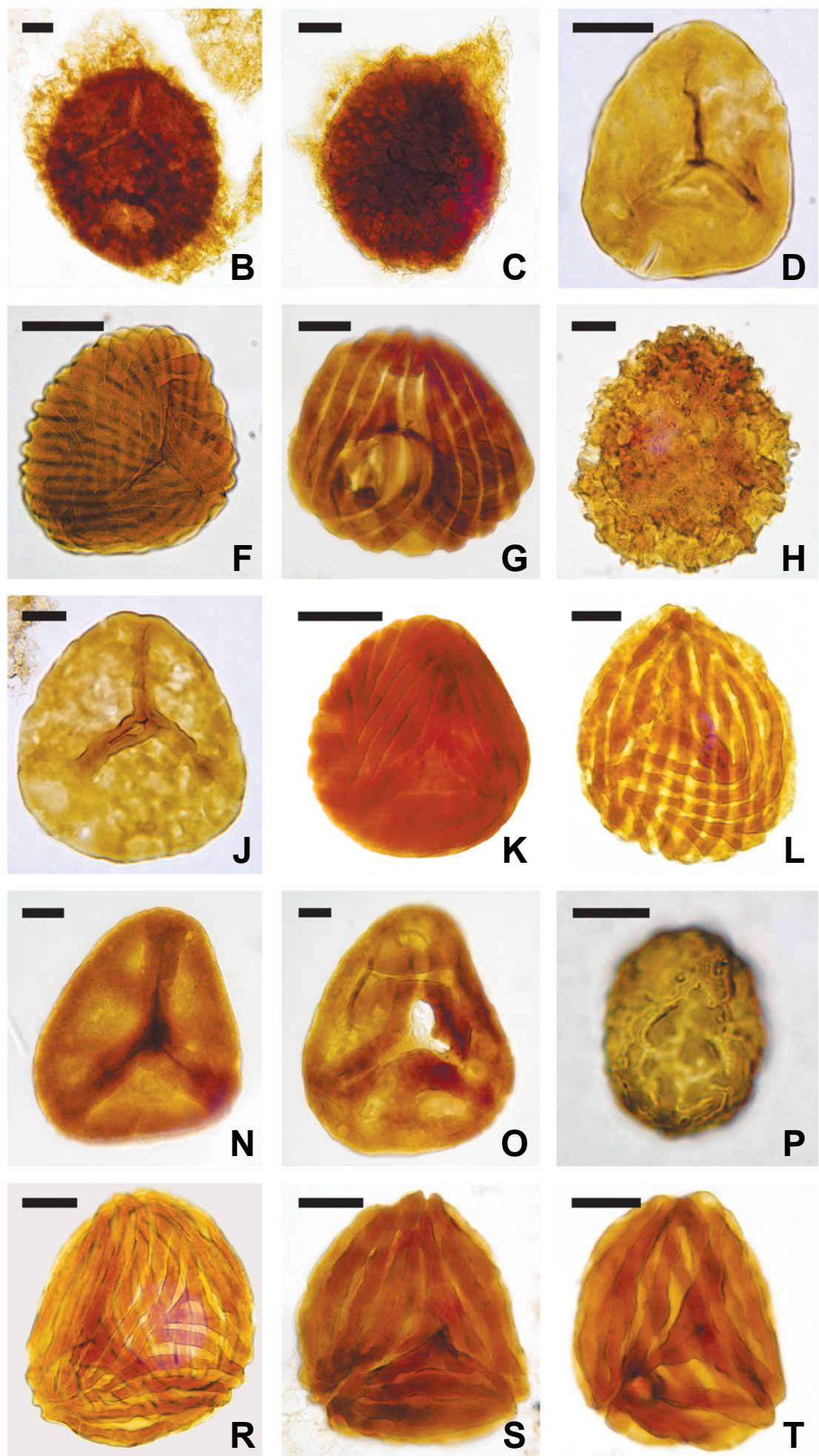

Figure 3. Trilete and monolete spores. Sample/slide numbers, England Finder coordinates and collection acronym are indicated for all specimens. A, Auritulinasporites sp., 8449A: Z22/2 MPLP; B-C, Balmeisporites sp. 1, B. 8449G: R41 MPLP, C. 8449F: M29/4 MPLP; D, Biretisporites sp., 8449F: N33/3 MPLP; E, ?Ceratosporites sp., 8449C: E29/4 MPLP; F, Cicatricosisporites cuneiformis Pocock, 1964, 8449B: X34 MPLP; G, Cicatricosisporites sp. 1 (in Narváez et al., 2013), 8435B: T21/1 MPLP, distal view; H, ?Cristatitriletes sp., 8449U: P39 MPLP; I, Deltoidospora minor (Couper) Pocock, 1970, 8435P: G33/2 MPLP; J, Dictyophyllidites sp., 8449F: T35/1 MPLP; K, Fisciniasporites sp. cf. F. brevilaesuratus (Couper) Dettmann \& Clifford, 1992, 8436C: U41/2 MPLP, proximal view; L, Fisciniasporites sp. (in Narváez et al., 2013), 8449I: Y33/1 MPLP; M, Leptolepidites sp., 8449U: F23 MPLP; N-0,?Matonisporites sp., H. 8449F: D29/1 MPLP, I. 8449I: H35 MPLP; P, Polypodiisporites sp., 8435N: R37/1 MPLP, distal view; Q, ?Raistrickia sp., 8449X: L28/4 MPLP; R, Ruffordiaspora ludbrookiae (Dettmann) Dettmann \& Clifford, 1992, 8449H: G41/1 MPLP; S, Ruffordiaspora cf. R. ticoensis (Archangelsky \& Gamerro) Archangelsky A.; Archangelsky S.; Poiré \& Canessa, 2008, 8449F: D42/4 MPLP, proximal view; T, Ruffordiaspora sp. 1 (in Narváez et al., 2013), 8449K: Q49/3 MPLP, proximal view. Scales bars: A-D, F-I, M, N, R-T = $20 \mu \mathrm{m} ; \mathrm{E}, \mathrm{J}-\mathrm{L}, \mathrm{O}-\mathrm{Q}=10 \mu \mathrm{m}$. 

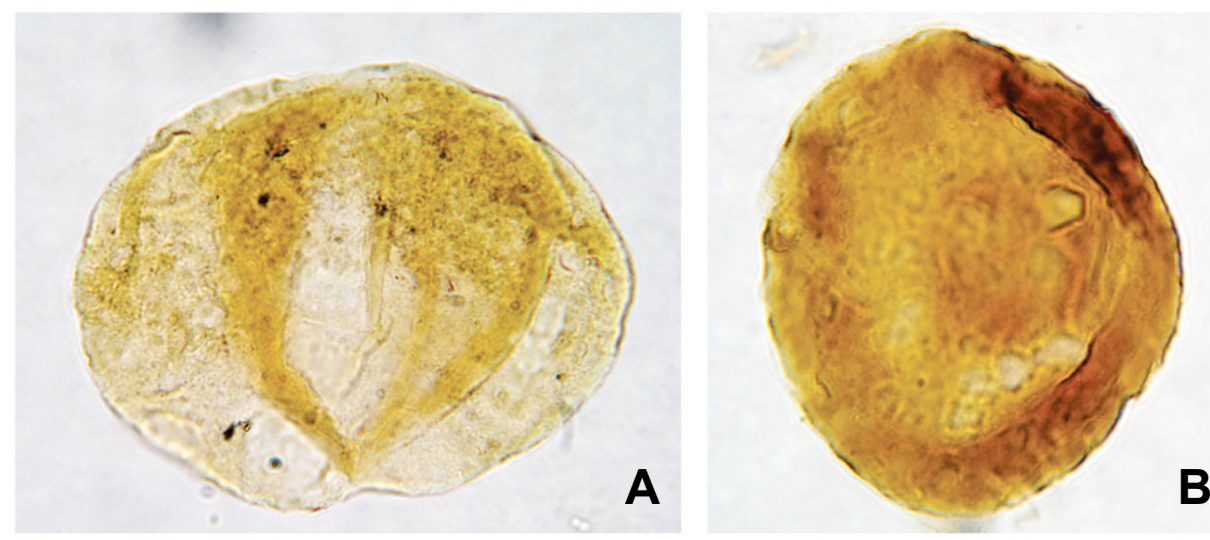

B
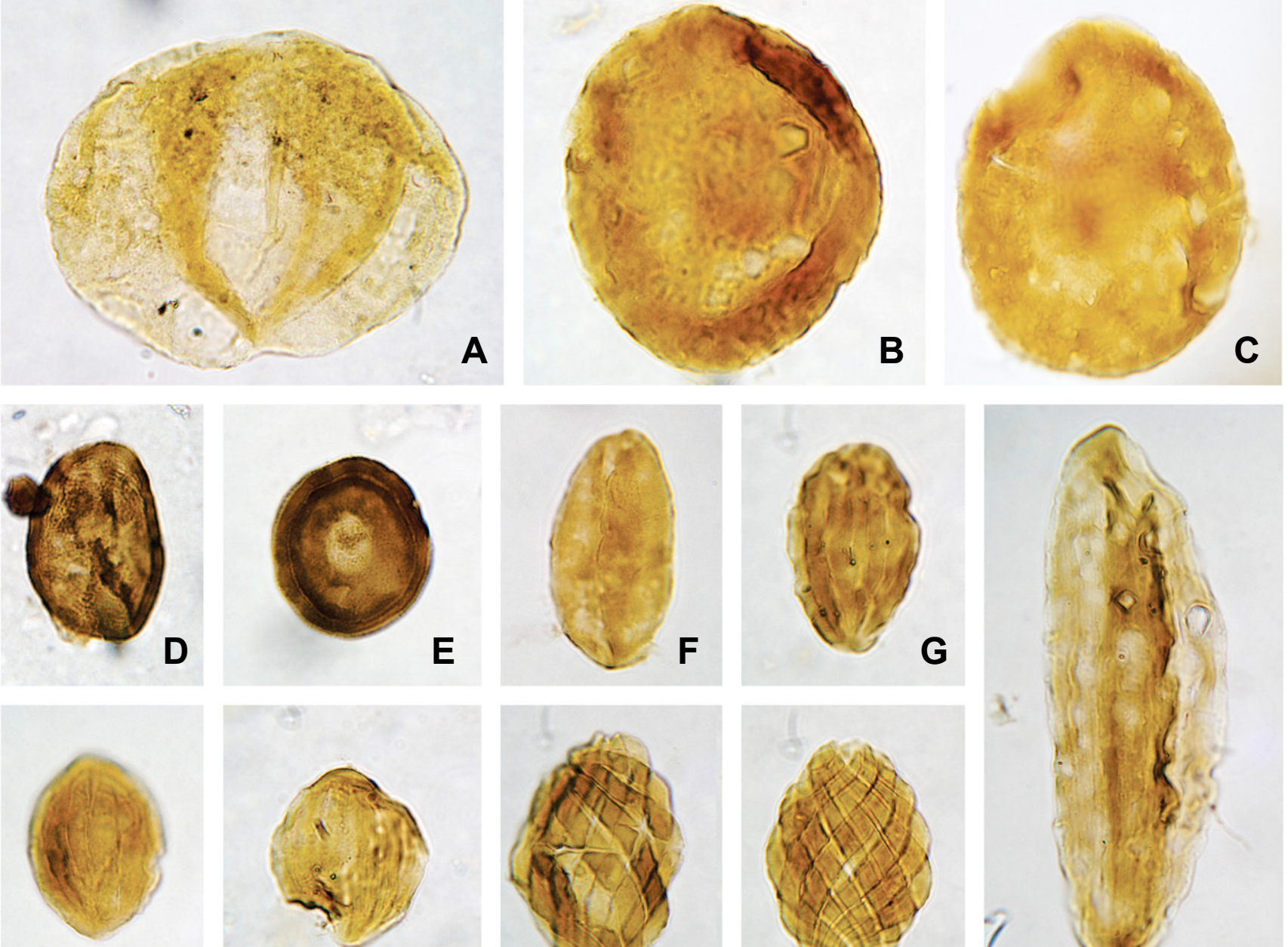

H
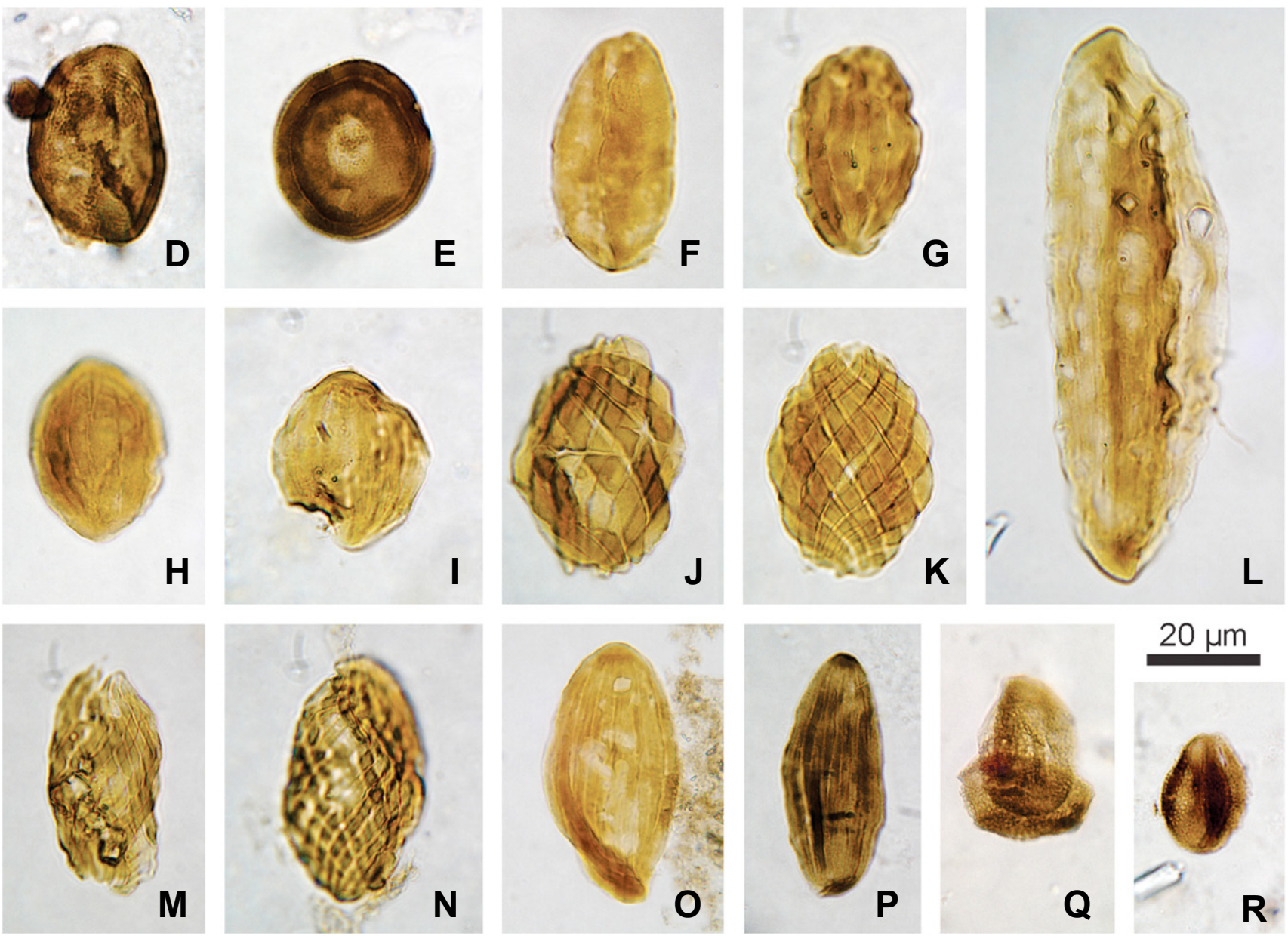

Figure 4. Pollen grains. Sample/slide numbers, England Finder coordinates and collection acronym are indicated for all specimens. A, Alisporites sp., 8435D: E34 MPLP; B-C, Balmeiopsis limbatus (Balme) Archangelsky, 1977, B. 8436F: W22 MPLP, C. 8436I: X25/2 MPLP; D, Classopollis classoides (Pflug) Pocock \& Jansonius, 1961, 8446F: R43 MPLP; E, Classopollis simplex (Danzé; Corsin \& Laveine) Reiser \& Williams, 1969, 8446M: U23/3 MPLP; F, Cycadopites sp., 8449A: H38/2 MPLP; G, Ephedripites caichiguensis (Volkheimer \& Quattrocchio) Narváez \& Sabino, 2008, 8449X: U30/1 MPLP; H-I, Ephedripites ovatus (Pierce) comb. nov., H. 8449E: T38/3 MPLP, I. 8436R: G40/1 MPLP; J-K, Gnetaceaepollenites barghoornii (Pocock) Lima, 1980, J. 8435D: S28/2 MPLP, K. 8436O: H24 MPLP; L, Ephedripites montanaensis Brenner, 1968, 8449W: Y34 MPLP; M-N, Gnetaceaepollenites jansonii (Pocock) Lima, 1980, M. 8435N: L29/4 MPLP, N. 8436R: P47/3 MPLP; O-P, Steevesipollenites binodosus Stover, 1964, O. 8435K: G21/4 MPLP, P. 8446C: P36 MPLP; Q-R, Tricolpites variabilis Burger, 1970, Q. 8448C: X39 MPLP, R. 8446D: N48/2 MPLP. Scale bar $=20 \mu \mathrm{m}$. 

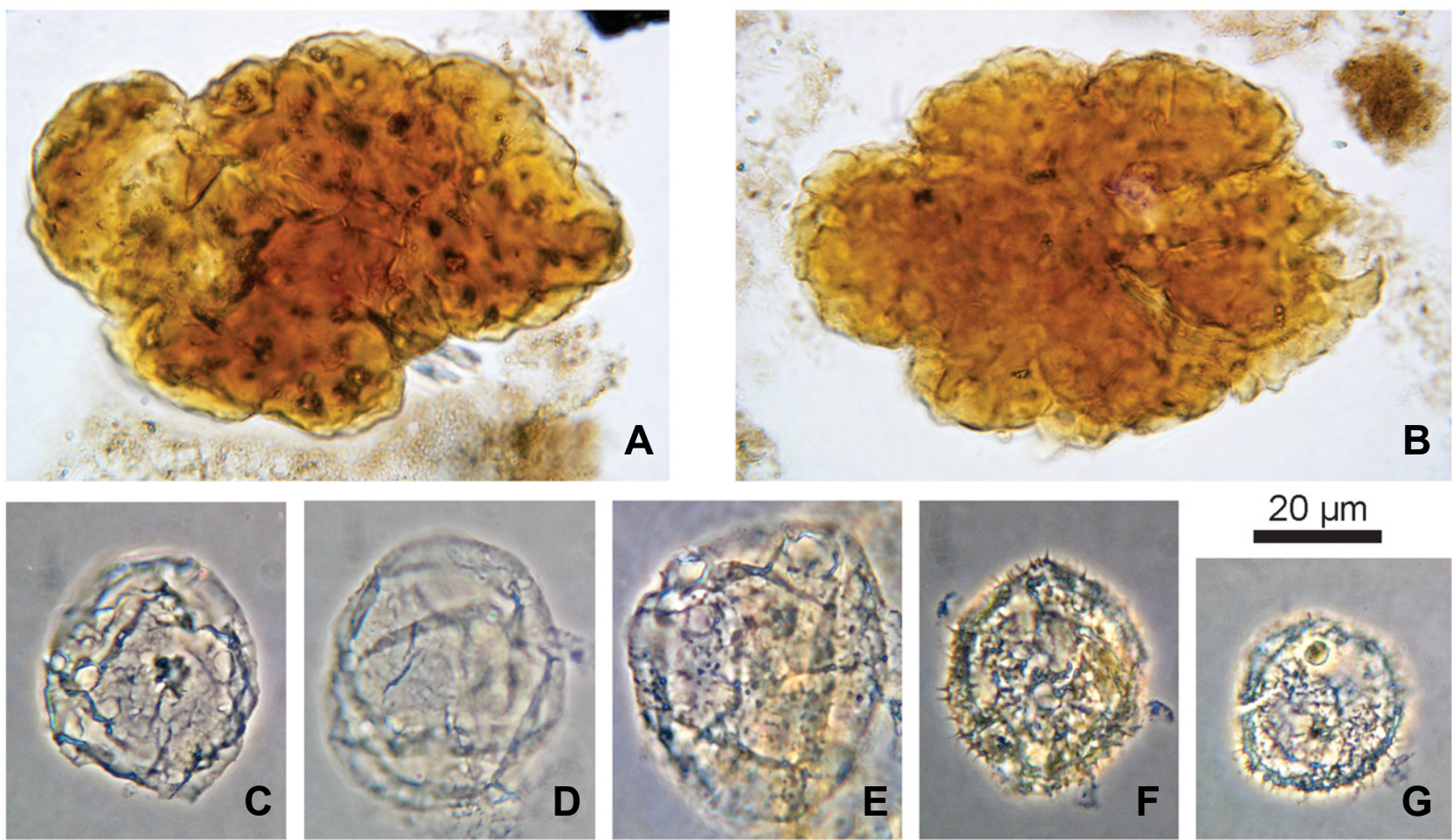

Figure 5. Aquatic species. Sample/slide numbers, England Finder coordinates and collection acronym are indicated for all specimens. A-B, Botryococcus sp., A. 8435O: D40/1 MPLP, B. 8435L: M41 MPLP; C-D, Leiosphaeridia-type 1, C. 8436B: X26/4 MPLP, D. 8436B: V23/1 MPLP; E, Leiosphaeridia-type 2, 8436B: F35 MPLP; F-G, Echinate vesicle indet., F. 8436D: K26/1 MPLP, G. 8436D: P25/3 MPLP. Scale bar = 20 $\mu$ m.

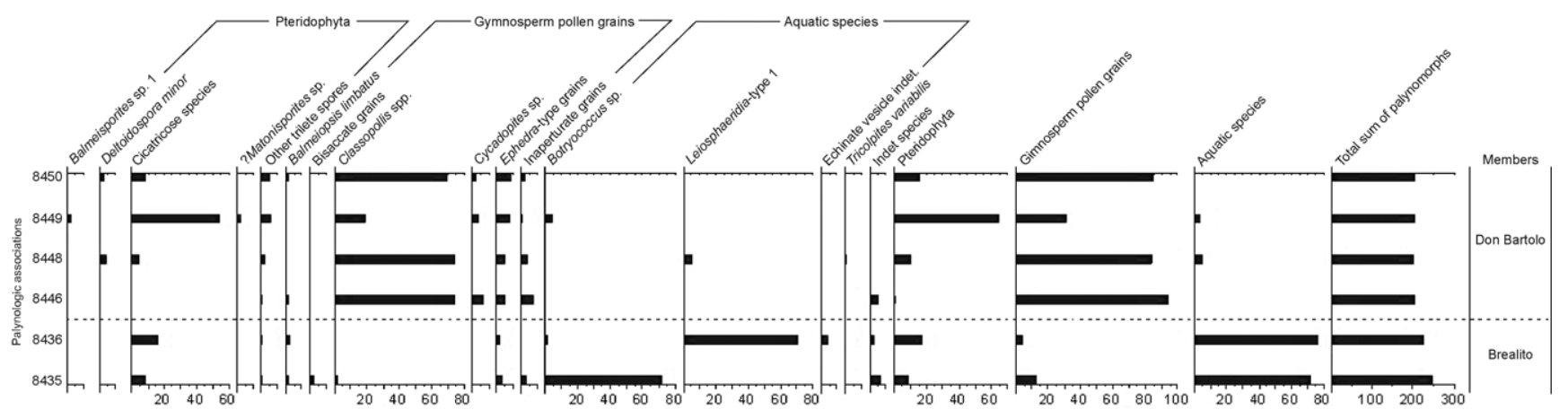

Figure 6. Percentages and total sum of species and suprageneric groups from the palynologic assemblages of the La Yesera Formation.

\& Zamaloa (2003), who mention that ephedroid pollen may indicate more diverse environments than today, such as brackish to coastal marine areas, areas associated with lakes or water courses, or even in tropical and subtropical forests. The authors agree with the assumption that Ephedra-type pollen suggests aridity, considering their present-day distribution in arid regions of Europe, Asia, and North and South America, including ten modern species present in Argentina, five of which are present in the northwest of the country (Hunziker \& Novara, 1998).

Among the spores, the Anemiaceae (three genera and seven species; Narváez et al., 2013) are dominant in the Don Bartolo Member assemblages, with the highest percentage in assemblage 8449 (54.2\%) (Figure 6). Schizaeales are currently distributed in tropical and subtropical areas. In Argentina, the order's three families have one genus each: Anemiaceae (Anemia), Lygodiaceae (Lygodium), and Schizaeaceae (Schizaea). In northwestern Argentina, Anemia has four species, including $A$. tomentosa, which is found in the dry soils of the Lerma valley, Salta Province (Martínez et al., 2003).

At the time of accumulation of the Don Bartolo Member, there were alluvial fans throughout the whole basin, and desiccation cracks indicate periodic drying of the bodies of water (Sabino, 2004). The palynologic assemblages described here agree with these seasonal climatic conditions, with dry periods and well-drained soils indicated by the high representation of thermophilous, and drought adapted Classopollis associated with ephedroid pollen. 
The notable scarcity of angiosperms in the assemblages from both members may be attributed to post-depositional taphonomic processes, or to the probable low abundance of angiosperm plants near the site. In the overlying Las Curtiembres Formation (Campanian-Maastrichtian?), Narváez \& Sabino (2008) indicate the presence of seven angiosperm species in poorly preserved palynoflora.

The regional climate inferred for the time of accumulation of the top levels of the La Yesera Formation is subtropical to semiarid, a conclusion based on the present-day distribution of palynomorph families found in this study (i.e. Anemiaceae, Ephedraceae, Lycopodiaceae/Selaginellaceae), and the absence of indicators of temperate conditions.

\section{PALYNOSTRATIGRAPHIC ANALYSIS}

Within Argentina, the palynoflora of the La Yesera Formation has similarities to the La Cantera Formation (Late Aptian, San Luis Basin, central-western Argentina; Prámparo, 1989b). Common morphotypes are Balmeiopsis limbatus, Classopollis simplex, and Gnetaceaepollenites barghoornii, the occurrence of abundant aquatic forms such as Leiosphaeridia, and the Echinate vesicle indet. (aff. Comasphaeridium?). In both, Anemiaceae, Cheirolepidaceae, and Ephedraceae families are diverse and abundant.

The authors can only make limited comparisons with other assemblages from mid-Cretaceous formations of southern Argentina (i.e. Austral, San Jorge, and Neuquén basins). For example, the La Yesera Formation palynoflora is similar to that of the Late Albian-Cenomanian Kachaike Formation (Austral Basin; Archangelsky \& Llorens, 2003, 2005, 2009; Barreda \& Archangelsky, 2006; Archangelsky \& Archangelsky, 2010); both show a predominance of Classopollis and the presence of bisaccate grains and cicatricose spores (Cicatricosisporites cuneiformis, Ruffordiaspora ludbrookiae, and $R$. cf. $R$. ticoensis; Narváez et al., 2013). There are only three genera (Alisporites, Cicatricosisporites, and Classopollis) in common with the Late Albian-Cenomanian Caleta Olivia Member of the Cañadón Seco Formation (San Jorge Basin; Archangelsky et al., 1994). Finally, there are three species (Deltoidospora minor, Classopollis classoides, and $C$. simplex) also found in the Huitrín Formation in the Neuquén Basin (Valanginian-Albian; Volkheimer \& Salas, 1976; Volkheimer, 1980); Ephedripites ovatus, Cicatricosisporites sp. and the genus Cycadopites are found in the La Yesera and Huincul Formations (Albian?-Cenomanian; Vallati, 2001).

The genus Balmeisporites originated in the Tethyan region during the Barremian or Early Aptian and then migrated to austral areas in the Late Aptian (Dettmann, 1995). This genus has been found in Albian-Campanian sediments from the Northern Hemisphere and Australia (Kovach \& Batten, 1989; Dettmann, 1995). In Argentina, B. holodictyus has been recorded in Albian strata of the Kachaike Formation, Patagonia (Baldoni \& Batten, 1991; Villar de Seoane \& Archangelsky, 2008).

Among gymnosperms, Ephedripites ovatus (Pierce) comb. nov. has been recorded in Albian-Cenomanian sediments from Argentina (Vallati, 2001), Brazil (Lima, 1980), Canada (Singh, 1964), Egypt (Schrank \& Ibrahim, 1995), and the USA (Pierce, 1961; Paden Phillips \& Felix, 1971). Balmeiopsis limbatus is usually found in Early Cretaceous sediments, particularly in southwestern Gondwana (Archangelsky \& Del Fueyo, 2010).

Hochuli et al. (2006) indicated the consistently occurrence of poly (tri) aperturate pollen grains in the early and midAlbian assemblages for the North Atlantic and Tethyan realm. In tropical areas, Heimhofer \& Hochuli (2010) mentioned the presence of tricolpate pollen since the Late Aptian (Rio da Batateira Formation, Araripe Basin) in northern Brazil. Regarding early angiosperms from Argentina, Prámparo et al. (2007) reviewed their evolutionary history based on existing palynologic and paleobotanic records. The oldest findings correspond to palynomorph genera Asteropollis and Clavatipollenites from Patagonian sediments of Barremian to Aptian age (see citations in Prámparo et al., 2007), but always subordinate in number to both gymnosperms and pteridophytes until the Campanian. Archangelsky et al. (2009) analysed angiosperm diversification in Argentina and concluded that tricolpate morphotypes evolved during the Albian (Stage III). In the Don Bartolo Member of the La Yesera Formation, the only three angiosperm grains found were assigned to Tricolpites variabilis (Figures $4 \mathrm{Q}-\mathrm{R}$ ). This species was previously recorded in Australia and included in the middle Albian and early Cenomanian, Phimopollenites pannosus Zone (Burger, 1993). In Argentina, Vallati (2001) mentioned T. cf. variabilis in Albian?-Cenomanian sediments from the Huincul Formation in the Neuquén Basin.

Hence, the current resolution of the pollen assemblages recovered from the top of the La Yesera Formation allows us to suggest an Albian/Cenomanian age for these records (Table 1), based mainly on tricolpate pollen grains, which have appeared in Argentina since the Albian (Archangelsky et al., 2009), and corroborated by the age range of Tricolpites variabilis. An Albian/Cenomanian age agrees with the sedimentologic data (Sabino, 2004), which suggest that the sedimentation of the Brealito Member levels occurred between the Late Albian and Cenomanian; the age also agrees with radiometric dating of the Isonza Basalt ( $96 \pm 5$ to $99 \pm 5 \mathrm{Ma}$; Valencio et al., 1976), indicating a Cenomanian age for sediments coeval with the Don Bartolo Member.

\section{ACKNOWLEDGEMENTS}

Thanks to W. Volkheimer and R. Marquillas, advisors of P. Narváez PhD Dissertation, that is partly presented here. S. Damiani collaborated during fieldwork. A. Moschetti assisted in the palynologic processing of samples. A. Carreras, M.R. Torres Deluigi, and E. Crespo of the LABMEM and F. Tricárico of the MACN collaborated in obtaining the SEM images. The authors acknowledge D. Peyrot and an anonymous reviewer for comments and suggestions that improved the manuscript. Thanks to M.J. Garcia and J.C. Coimbra for their editorial assistance. E. Marsh revised the English and F. Leite translated the abstract to Portuguese. This research was supported by 
Table 1. Stratigraphic ranges of selected species reported in southern Gondwana. 1. Prámparo (1994), Atta-Peters \& Salami (2006), Olivera et al. (2010), Eisawi et al. (2012); 2. Dettmann \& Cliford (1992), Cranwell \& Srivastava (2009), Narváez et al. (2013); 3. Lima (1978), Lima et al. (1980), Narváez et al. (2013); 4. Herngreen (1973), Lima (1980), Sinanoglu (1984), Prámparo (1989b), Vajda-Santivanez (1999); 5. Herngreen (1973), Kotova (1978), Lima (1980), Schrank \& Ibrahim (1995), Vajda-Santivanez (1999), Limarino et al. (2000); 6. Lima (1980), Schrank \& Ibrahim (1995), Vallati (2001); 7. Archangelsky et al. (2009), Heimhofer \& Hochuli (2010); 8. Kovach \& Batten (1989), Baldoni \& Batten (1991), Dettmann (1995), Villar de Seoane \& Archangelsky (2008); 9. Stover (1964), Herngreen (1973), Regali et al. (1974), Kotova (1978), Morgan (1978), Lima (1978, 1980), Lawal \& Moullade (1986), Schrank (1990), Jaillard (1997), Masure et al. (1998), Bettar \& Meon (2006), Boboye (2012), Ola-Buraimo \& Olúwájánà (2012); 10. Burger (1993), Vallati (2001).

\begin{tabular}{|c|c|c|c|c|c|c|c|c|c|c|c|c|c|}
\hline \multirow{3}{*}{$\begin{array}{l}\text { Period/ } \\
\text { Epoch/Age }\end{array}$} & \multirow{3}{*}{ Jurassic } & \multicolumn{12}{|c|}{ Cretaceous } \\
\hline & & \multicolumn{6}{|c|}{ Lower } & \multicolumn{6}{|c|}{ Upper } \\
\hline & & Berr & $\mathrm{Val}$ & $\mathrm{Hau}$ & Barr & Apt & Alb & Cen & Tur & Con & San & Cam & Maas \\
\hline \multicolumn{14}{|l|}{ Balmeiopsis limbatus $^{1}$} \\
\hline \multicolumn{14}{|l|}{ Ruffordiaspora ludbrookiae ${ }^{2}$} \\
\hline \multicolumn{14}{|l|}{ Fisciniasporites spp. ${ }^{3}$} \\
\hline \multicolumn{14}{|l|}{ Gnetaceaepollenites barghoornii ${ }^{4}$} \\
\hline \multicolumn{14}{|l|}{ Gnetaceaepollenites jansonii ${ }^{5}$} \\
\hline \multicolumn{14}{|l|}{ Ephedripites ovatus ${ }^{6}$} \\
\hline \multicolumn{14}{|l|}{ Tricolpate pollen grains ${ }^{7}$} \\
\hline \multicolumn{14}{|l|}{ Balmeisporites spp. ${ }^{8}$} \\
\hline \multicolumn{14}{|l|}{ Steevesipollenites binodosus ${ }^{9}$} \\
\hline Tricolpites variabilis ${ }^{10}$ & & & & & & & & & & & & & \\
\hline
\end{tabular}

FONCyT-ANPCyT (Fondo para la Inversión Científica y Tecnológica - Agencia Nacional de Promoción Científica y Tecnológica, PICT 12419, 12492, and 2010-1032), CONICET (Consejo Nacional de Investigaciones Científicas y Técnicas, PIP 5222), and CIUNSa (Consejo de Investigaciones de la Universidad Nacional de Salta, projects 1220 and 1281).

\section{REFERENCES}

Archangelsky, S. 1977. Balmeiopsis nuevo nombre genérico para el palinomorfo Inaperturopollenites limbatus Balme, 1957. Ameghiniana, 14:122-126.

Archangelsky, S. \& Archangelsky, A. 2010. Revisión taxonómica y estratigráfica de esporas cicatricosas del Cretácico Inferior de Patagonia. 2. Géneros Cicatricosisporites Potonié \& Gelletich y Ruffordiaspora Dettmann \& Clifford. Revista del Museo Argentino de Ciencias Naturales, 12:179-201.

Archangelsky, A.; Archangelsky, S.; Poiré, D.G. \& Canessa, N.D. 2008. Registros palinológicos en la Formación Piedra Clavada (Albiano) en su área tipo, provincia de Santa Cruz, Argentina. Revista del Museo Argentino de Ciencias Naturales, 10:185-198.

Archangelsky, S.; Baldoni, A.; Gamerro, J.C. \& Seiler, J. 1983. Palinología estratigráfica del Cretácico de Argentina Austral. II. Descripciones sistemáticas. Ameghiniana, 20:199-226.

Archangelsky, S.; Bellosi, E.S.; Jalfin, G.A. \& Perrot, C. 1994. Palynology and alluvial facies from the mid-Cretaceous of Patagonia, subsurface of San Jorge Basin, Argentina. Cretaceous Research, 15:127-142. doi:10.1006/cres.1994.1006

Archangelsky, S. \& Del Fueyo, G.M. 2010. Endemism of Early Cretaceous conifers in western Gondwana. In: C.T. Gee (ed.) Plants in Mesozoic Time. Morphological innovations, phylogeny, ecosystems, Indiana University Press, p. 247-268.

Archangelsky, S. et al. 2009. Early angiosperm diversification: evidence from southern South America Cretaceous Research, 30:1073-1082. doi:10.1016/j.cretres.2009.03.001

Archangelsky, S. \& Llorens, M. 2003. Palinología de la Formación Kachaike, Cretácico Inferior de la Cuenca Austral, provincia de Santa Cruz. 1- Esporas lisas y cinguladas. Ameghiniana, 40:71-80.

Archangelsky, S. \& Llorens, M. 2005. Palinología de la Formación Kachaike, Cretácico Inferior de la Cuenca Austral, provincia de Santa Cruz. 2- Esporas. Ameghiniana, 42:311-328.

Archangelsky, S. \& Llorens, M. 2009. Palinología de la Formación Kachaike, Cretácico Inferior de la Cuenca Austral, provincia de Santa Cruz. Granos de polen de gimnospermas. Ameghiniana, 46:225-234.

Archangelsky, S. \& Zamaloa, M.C. 2003. Primeros resultados palinológicos del Paleógeno del sector oriental de la Sierra La Colonia, provincia del Chubut, Argentina. Revista del Museo Argentino de Ciencias Naturales, Nueva Serie, 5:119-123.

Atta-Peters, D. \& Salami, M.B. 2006. Aptian-Maastrichtian palynomorphs from the offshore Tano Basin, western Ghana. Journal of African Earth Sciences, 46:379-394. doi:10.1016/j. jafrearsci.2006.07.002

Azcuy, C.L. 1975. Miosporas del Namuriano y Westfaliano de la comarca Mazalán-Loma Larga, provincia de La Rioja, Argentina. I. Localización geográfica y geológica de la comarca y descripción sistemática. Ameghiniana, 12:1-69.

Baldoni, A.M.; Askin, R.A. \& Ragona, D. 2001. Palynology of the Lower Cretaceous Kachaike Formation, Santa Cruz province, Argentina. In: INTERNATIONAL PALYNOLOGICAL CONGRESS, 9, 1996. Procceedings, Houston, p.191-200.

Baldoni, A.M. \& Batten, D.J. 1991. Megaspores from the Lower Cretaceous Kachaike Formation, Santa Cruz Province, Argentina. Neues Jahrbuch für Geologie und Paläontologie, Abhandlungen, 182:377-393.

Barreda,V. \& Archangelsky, S. 2006. The southernmost record of tropical pollen grains in the mid-Cretaceous of Patagonia Argentina. Cretaceous Research, 27:778-78. doi:10.1016/j. cretres.2006.02.002

Batten, D.J. \& Grenfell, H.R. 1996. Chapter 7D: Botryococcus. In: J. Jansonius \& D.C. McGregor (eds.) Palynology: principles and applications, American Association of Stratigraphic Palynologists Foundation, p. 205-214. 
Batten, D.J. \& Lister, J.K. 1988. Early Cretaceous dinoflagellate cysts and chlorococcalean algae from freshwater and low salinity palynofacies in the English Wealden. Cretaceous Research, 9:337-367. doi:10.1016/0195-6671(88)90007-9

Batten, D.J. \& MacLennan, A.M. 1984. The paleoenvironmental significance of the conifer family Cheirolepidiaceae in the Cretaceous of Portugal. In: SYMPOSIUM ON MESOZOIC TERRESTRIAL ECOSYSTEMS, 3, 1984. Short Papers, Tübingen, p. 7-12.

Bettar, I. \& Meon, H. 2006. La palynoflore continentale de l'Albien du basin d'Agadir-Essaouira (Maroc). Revue de Palébiologie, 25:593-631.

Boboye, O.A. 2012. Late Albian-Eocene palynological biostratigraphy of three wells in the Nigerian sector of Chad (Bornu) Basin. Journal of Mining and Geology, 48:127-157.

Boso, M.A.; Brandán, E.M. \& Salfity, J.A. 1984. Estratigrafía y paleoambientes del Subgrupo Pirgua (Cretácico) en la comarca de Brealito, provincia de Salta. In: CONGRESO GEOLÓGICO ARGENTINO, 9, 1984. Actas, San Carlos de Bariloche, p.108-123.

Bossi, G.E. \& Wampler, M. 1969. Edad del Complejo Alto de las Salinas y Formación El Cadillal según el método K-Ar. Acta Geológica Lilloana, 10:141-160.

Brenner, G.J. 1968. Middle Cretaceous spores and pollen from northeastern Peru. Pollen et Spores, 10:341-383.

Burger, D. 1970. Early Cretaceous angiospermous pollen grains from Queensland. Bureau of Mineral Resources, Bulletin, 116:1-16.

Burger, D. 1993. Early and middle Cretaceous angiosperm pollen grains from Australia. Review of Palaeobotany and Palynology, 78:183-234. doi:10.1016/0034-6667(93)90065-3

Cookson, I.C. \& Dettmann, M.E. 1958a. Cretaceous "megaspores" and a closely associated microspore from the Australian region. Micropaleontology, 4:39-49. doi:10.2307/1484250

Cookson, I.C. \& Dettmann, M.E. 1958b. Some trilete spores from Upper Mesozoic deposits in the eastern Australian region. Proceedings of the Royal Society of Victoria, 70:95-128.

Couper, R.A. 1958. British Mesozoic and Cainozoic plant microfossils. Palaeontographica Abteilung B, 103:75-179.

Cranwell, L.M. \& Srivastava, S.K. 2009. An Early Cretaceous (Hauterivian) spore-pollen assemblage from Southern Chile. Palynology, 33:241-280. doi:10.2113/gspalynol.33.1.241

Dettmann, M.E. 1963. Upper Mesozoic microfloras from south-eastern Australia. Proceedings of the Royal Society of Victoria, 77:1-148.

Dettmann, M.E. 1995. Ultrastructure and biogeography of Balmeisporites Cookson \& Dettmann, 1958. Review of Palaeobotany and Palynology, 89:287-296. doi:10.1016/00346667(95)00005-4

Dettmann, M.E. \& Clifford, H.T. 1992. Phylogeny and biogeography of Ruffordia, Mohria and Anemia (Schizaeaceae) and Ceratopteris (Pteridaceae): evidence from in situ and dispersed spores. Alcheringa, 16:269-314. doi:10.1080/03115519208619111

Dettmann, M.E. \& Jarzen, D.M. 1988. Angiosperm pollen from uppermost Cretaceous strata of southeastern Australia and the Antarctic Peninsula. Association of Australasian Palaeontologists, 5:217-237.

Downie, C. 1957. Microplankton from the Kimeridge Clay. Quarterly Journal of the Geological Society of London, 112:413-434.

Downie, C. \& Sarjeant, W.A.S. 1963. On the interpretation and status of some hystrichosphere genera. Palaeontology, 6:83-96.

Eisawi, A.A.M.; Ibrahim, A.B.; Rahim, O.B.A. \& Schrank, E. 2012. Palynozonation of the Cretaceous to Lower Paleogene strata of the Muglad Basin, Sudan. Palynology, 36:191-207. doi:10.108 0/01916122.2011.633634
Eisenack, A. 1958. Tasmanites Newton 1875 und Leiosphaeridia n. g. als Gattungen der Hystrichosphaeridea. Palaeontographica Abteilung, 110:1-19.

Eshet, Y. 1990. Paleozoic-Mesozoic palynology of Israel: Palynological aspects of the Permo-Triassic succession in the subsurface of Israel. Geological Survey of Israel, 81:1-57.

Fensome, R.A. 1987. Taxonomy and biostratigraphy of schizaealean spores from the Jurassic-Cretaceous boundary beds of the Aklavik Range, District of Mackenzie. Palaeontographica Canadiana, 4:1-49.

Frederiksen, N.O. 1985. Review of Early Tertiary sporomorph paleoecology. American Association of Stratigraphic Palynologists, 15:1-91.

García, G.B. 1995. Palinología de la Formación El Imperial, Paleozoico Superior, Cuenca de San Rafael, Argentina. Parte I: Esporas. Ameghiniana, 32:315-339.

Guy-Ohlson, D. 1992. Botryococcus as an aid in the interpretation of palaeoenvironment and depositional processes. Review of Palaeobotany and Palynology, 71:1-15. doi:10.1016/00346667(92)90155-A

Guy-Ohlson, D. 1998. The use of the microalga Botryococcus in the interpretation of lacustrine environments at the Jurassic-Cretaceous transition in Sweden. Palaeogeography, Palaeoclimatology, Palaeoecology, 140:347-356. doi:10.1016/ S0031-0182(98)00019-4

Heimhofer, U. \& Hochuli, P.A. 2010. Early Cretaceous angiosperm pollen from a low-latitude succession (Araripe Basin, NE Brazil). Review of Palaeobotany and Palynology, 161:105-126. doi:10.1016/j.revpalbo.2010.03.010

Helby, R.; Morgan, R. \& Partridge, A.D. 1987. A palynological zonation of the Australian Mesozoic. Memoirs of the Association of Australasian Palaeontologists, 4:1-94.

Herngreen, G.F.W. 1973. Palynology of Albian-Cenomanian strata of borehole 1-QS-1-MA, State of Maranhão, Brazil. Pollen et Spores, 15:515-555.

Herngreen, G.F.W. \& Chlonova, A.F. 1982. Cretaceous microfloral provinces. Pollen et Spores, 23:441-555.

Hochuli, P.A.; Heimhofer, U. \& Weissert, H. 2006. Timing of early angiosperm radiation: recalibrating the classical succession. Journal of the Geological Society, 163:587-594. doi:10.1144/0016-764905-135

Hunziker, J.H. \& Novara, L.J. 1998. Ephedraceae Dumort. Aportes Botánicos de Salta, 5:1-14.

Jaillard, E. 1997. Síntesis estratigráfica y sedimentológica del Cretáceo y Paleógeno de la Cuenca Oriental del Ecuador. Quito, Informe Final del Convenio Orstom-Petroproducción, 164 p.

Jansonius, J. \& Hills, L.V. 1976. Genera file of fossil spores and Pollen. Calgary, University of Calgary Press, $36 \mathrm{p}$.

Jarzen, D.M. \& Dettmann, M.E. 1989. Taxonomic revision of Tricolpites reticulatus Cookson ex Couper, 1953 with notes on the biogeography of Gunnera L. Pollen et Spores, 31:97-112.

Kotova, I.Z. 1978. Spores and pollen from Cretaceous deposits of the eastern north Atlantic Ocean, deep sea drilling project, Leg 41, Sites 367 and 370. In: Y. Lancelot et al. (eds.) Initial Reports of the Deep Sea Drilling Project, U.S. Printing Office, p. 841-881.

Kovach, W.L. \& Batten, D.J. 1989. Worlwide stratigraphic occurrences of Mesozoic and Tertiary megaspores. Palynology, 13:247-277. doi:10.1080/01916122.1989.9989362

Kützing, F.T. 1849. Species algarum. F.A. Leipzig, Brockhaus, 922 p.

Lawal, O. \& Moullade, M. 1986. Palynological biostratigraphy of Cretaceous sediments in the Upper Benue Basin, NE Nigeria. Revue de Micropaléontologie, 29:61-83. 
Lima, M.R. 1978. Palinología da Formação Santana (Cretáceo do nordeste do Brasil). Introdução geológica e descrição sistemática dos esporos da subturma Azonotriletes. Ameghiniana, 15:333-365.

Lima, M.R. 1980. Palinologia da Formação Santana (Cretáceo do nordeste do Brasil). 3. Descrição sistemática dos polens da Turma Plicates (Subturma Costates). Ameghiniana, 17:15-47.

Lima, M.R. 1983. Paleoclimatic reconstruction of the Brazilian Cretaceous based on palynological data. Revista Brasileira de Geociências, 13:223-228.

Lima, M.R.; Fulfaro, V.J. \& Bartorelli, A. 1980. Análise palinológica de sedimentos cretáceos da região de Marabá, Estado do Pará. Boletim do IGc-USP, 11:155-161.

Limarino, O.; Net, L.; Gutiérrez, P.; Barreda, V.; Caselli, A. \& Ballent, S. 2000. Definición de la Formación Ciénaga del Río Huaco (Cretácico Superior), Precordillera central, San Juan, Argentina. Revista de la Asociación Geológica Argentina, 55:83-99.

Mädler. K. 1964. Die geologische Verbreitung von Sporen in der deutschen Trias. Beihefte zum Geologischen, 65:1-147.

Marquillas, R.A.; del Papa, C. \& Sabino, I.F. 2005. Sedimentary aspects and paleoenvironmental evolution of a rift basin: Salta Group (Cretaceous-Paleogene), northwestern Argentina. International Journal of Earth Sciences, 94:94-113. doi:10.1007/ s00531-004-0443-2

Martínez, O.G.; de la Sota, E.R. \& Narváez, P.L. 2003. Schizaeaceae Kaulf. Aportes Botánicos de Salta, 7:1-7.

Martínez, M.A.; Quattrocchio, M.E. \& Prámparo, M.B. 2005. Análisis palinológico de la Formación Los Molles, Grupo Cuyo, Jurásico Medio de la Cuenca Neuquina, Argentina. Ameghiniana, 42:67-92.

Masure, E.; Rauscher, R.; Dejax, J.; Schuler, M. \& Ferré, B. 1998. Cretaceous-Paleocene palynology from the Côte D'Ivoire-Ghana transform margin, sites 959, 960, 961, and 962. In: J. Mascle; G.P. Lohmanm \& M. Moullade (eds.) Initial Reports of the Deep Sea Drilling Project, U.S. Printing Office, p. 253-276.

Medina, F.; Archangelsky, S.; Guler, V.; Archangelsky, A. \& Cárdenas, O. 2008. Estudio bioestratigráfico integrado del perfil La Horqueta (límite Aptiano-Albiano), Lago Cardiel, Patagonia, Argentina. Revista del Museo Argentino de Ciencias Naturales, 10:273-289.

Morgan, R. 1978. Albian to Senoanian palynology of site 364, Angola Basin. In: H.M. Bolli et al. (eds.) Initial Reports of the Deep Sea Drilling Project, U.S. Printing Office, p. 915-951.

Narváez,P.L.; Mego, N.\& Prámparo, M.B. 2013. Cretaceous cicatricose spores from north and central-western Argentina. Taxonomic and biostratigraphic discussion. Palynology, 37:202-217. doi:10.1080/01916122.2012.762062

Narváez, P.L. \& Sabino, I.F. 2008. Palynology and paleoenvironment of the Las Curtiembres Formation (Late Cretaceous, Salta Group Basin), Las Conchas creek area, northwestern Argentina. Ameghiniana, 45:473-482.

Ola-Buraimo, A.O. \& Olúwájánà, O.A. 2012. Sedimentological and palynological assessment of Bima Group, Bornu Basin, Northeastern Nigeria. The Pacific Journal of Science and Technology, 13:397-406.

Olivera, D.E.; Martínez, M.A.; Zavala, C. \& Ballent, S.C. 2010. Los depósitos oxfordiano-kimmmeridgianos de la Formación Lotena: nuevas perspectivas en la estratigrafía del Jurásico Tardío de la Cuenca Neuquina, Argentina. Ameghiniana, 47:479-499.

Ottone, E.G. \& Mancuso, A.C. 2006. Algas Chlorococcales como indicadores paleoambientales: nuevos datos de la Formación Los Rastros, Triásico del centro-oeste de Argentina. Revista del Museo Argentino de Ciencias Naturales, 8:209-220.

Ottone, E.G.; Mancuso, A.C. \& Resano, M. 2005. Miospores and chlorococcacean algae from the Los Rastros Formation, Middle to Upper Triassic of central-western Argentina. Ameghiniana, 42:347-362.

Paden Phillips, P. \& Felix, C. 1971. A study of Lower and Middle Cretaceous spores and pollen from southeastern United States. I. Spores. Pollen et Spores, 13:279-348.

Perez Loinaze, V.S.; Archangelsky, S. \& Cladera, G. 2012. Palynostratigraphic study of the Early Cretaceous Río Mayer and Kachaike formations at the Quebrada El Moro Section, Austral Basin, southwestern Argentina. Cretaceous Research, 34:161-171. doi:10.1016/j.cretres.2011.10.015

Pierce, R.L. 1961. Lower Upper Cretaceous plant microflora from Minnesotta. Bulletin of the Minnesota Geological Survey, 42:1-86.

Pocock, S.A.J. 1964. Pollen and spores of the Chlamydospermidae and Schizaeaceae of the Saskatoon area of Saskatchewan. Grana Palynologica, 5:129-209. doi:10.1080/00173136409430013

Pocock, S.A.J. 1970. Palynology of the Jurassic sediments of western Canada. Part 1. Terrestrial species. Palaeontographica Abteilung $B$, 130:12-72.

Pocock, S.A.J. \& Jansonius, J. 1961. The pollen genus Classopollis Pflug, 1953. Micropaleontology, 7:439-449.

Potonié, R. 1958. Synopsis der Gattungen der Sporae dispersae II. Teil: Sporites (Nachträge Saccites, Aletes, Praecolpates, Poliplicates, Monocolpates). Beihefte Geologischen, 31:1-114.

Prámparo, M.B. 1988. Nuevos aportes a la palinología de la Formación La Cantera, Cretácico de la Cuenca de San Luis, en su localidad tipo. In: CONGRESO ARGENTINO DE PALEONTOLOGÍA Y BIOESTRATIGRAFÍA, 4, 1986. Actas, Mendoza, Argentina, p. 43-50.

Prámparo, M.B. 1989a. Las esporas de Schizaeaceae (Cicatricosisporites y Appendicisporites) del Cretácico Inferior, Cuenca de San Luis, Argentina. Revista Española de Micropaleontología, 21:355-372.

Prámparo, M.B. 1989b. Palinología estratigráfica del Cretácico de la Cuenca de San Luis. Programa de postgrado en Geología, Facultad de Ciencias Exactas, Físico-químicas y Naturales, Universidad Nacional de Río Cuarto, Ph.D. thesis, 243 p.

Prámparo, M.B. 1990. Palynostratigraphy of the Lower Cretaceous of the San Luis Basin, Argentina. Its place in the Lower Cretaceous floral provinces pattern. Neues Jahrbuch für Geologie und Paläontologie, 181:255-266.

Prámparo, M.B. 1994. Lower Cretaceous palynoflora of the La Cantera Formation, San Luis Basin: correlation with other Cretaceous palynofloras of Argentina. Cretaceous Research, 15:193-203. doi:10.1006/cres. 1994.1010

Prámparo, M.B.; Ballent, S.C.; Gallego, O.F. \& Milana, J.P. 2005. Paleontología de la Formación Lagarcito (Cretácico Inferior) en la provincia de San Juan, Argentina. Ameghiniana, 42:93-114.

Prámparo, M.B. \& Milana, J.P. 1999. Palynological and sedimentological data from the continental Lower Cretaceous Lagarcito Formation, San Juan Province, Argentina. In: INTERNATIONAL SIMPOSIUM ON MESOZOIC TERRESTRIAL ECOSYSTEMS, 7, 1999. Resúmenes, Buenos Aires, p. 52.

Prámparo, M.B.; Quattrocchio, M.E.; Gandolfo, M.A.; Zamaloa, M.C. \& Romero, E. 2007. Historia evolutiva de las angiospermas (Cretácico-Paleógeno) en Argentina a través de los registros paleoflorísticos. Ameghiniana, 50:157-172.

Punt, W.P.; Hoen P.P.; Blackmore, S.; Nilsson, S. \& Le Thomas, A. 2007. Glossary of pollen and spore terminology. Review of Palaeobotany and Palynology, 143:1-81. doi:10.1016/j. revpalbo.2006.06.008

Quattrocchio, M.E.; Volkheimer, W.; Marquillas, R.A. \& Salfity, J.A. 2005. Palynostratigraphy, palaeobiogeography and evolutionary significance of the Late Senonian and Early Palaeogene palynofloras of the Salta Group, northern Argentina. Revista Española de Micropaleontología, 37:259-272. 
Rabinowitz, P.D. \& LaBrecque, J. 1979. The Mesozoic South Atlantic Ocean and evolution of its continental margin. Journal of Geophysical Research, 84:5973-6002. doi:10.1029/ JB084iB11p05973

Regali, M.S.P.; Uesugui, N. \& Santos, A.S. 1974. Palinologia dos sedimentos Meso-Cenozóicos do Brasil. Parte II. Boletim Técnico da Petrobrás, 17:263-301.

Reiser, R.F. \& Williams, A.J. 1969. Palynology of the Lower Jurassic sediments of the Northern Surat Basin, Queensland. Canberra, Geological Survey of Queensland, p. 1-24 (Paleontological Papers 15).

Reyes, F.C. \& Salfity, J.A. 1973. Consideraciones sobre la estratigrafía del Cretácico (Subgrupo Pirgua) del noroeste argentino. In: CONGRESO GEOLÓGICO ARGENTINO, 5, 1972. Actas, Villa Carlos Paz, p. 355-385.

Rodríguez Amenábar, C. \& Ottone, E.G. 2003. La aplicación de Botryococcus (Chlorococcales) como indicador paleoambiental en el Triásico de Argentina. Revista Española de Micropaleontología, 35:161-169.

Sabino, I.F. 2002. Geología del Subgrupo Pirgua (Cretácico) del Noroeste Argentino. Programa de posgrado en Geología, Facultad de Ciencias Naturales, Universidad Nacional de Salta, Ph.D. thesis, $260 \mathrm{p}$.

Sabino, I.F. 2004. Estratigrafía de la Formación La Yesera (Cretácico): Base del relleno sinrift del Grupo Salta, noroeste argentino. Revista de la Asociación Geológica Argentina, 59:341-359.

Salfity, J.A. \& Marquillas, R.A. 1994. Tectonic and sedimentary evolution of the Cretaceous-Eocene Salta Group Basin, Argentina. In: J.A. Salfity (ed.) Cretaceous Tectonics of the Andes, Teubner Verlag, Earth Evolution Sciences, p. 266-315. doi:10.1007/978-3-322-85472-8_6

Schopf, J.M.; Wilson, L.R. \& Bentall, R. 1944. An annotated synopsis of Palaeozoic fossil spores and the definition of generic groups. Champaign, Illinois State Geological Survey, 72 p. (Report of Investigations 91).

Schrank, E. 1990. Palynology of the clastic Cretaceous sediments between Dongola and Wadi Muqaddam, northern Sudan. Berliner Geowissenschaftliche Abhandlungen A, 120:149-168.

Schrank, E. \& Ibrahim, M.I.A. 1995. Cretaceous (AptianMaastrichtian) palynology of foraminifera-dated wells (KRM-1, AG-18) in northwestern Egypt. Berliner Geowissenschaftliche Abhandlungen A, 177:1-44.

Sempere, Th. 1995. Phanerozoic evolution of Bolivia and adjacent regions. Tulsa, American Association of Petroleum Geologists, p. 207-230 (Memoir 62).

Sinanoglu, E. 1984. Early Cretaceous palynomorphs from the Zuata area, eastern Venezuela. Boletim do IGc-USP, 15:116-128.

Singh, C. 1964. Microflora of the Lower Cretaceous Manville Group, East-Central Alberta. Alberta Research Council, 15:1-239.

Srivastava, S.K. 1968. Ephedralean pollen from the Upper Cretaceous Edmonton Formation of Alberta (Canada) and their paleoecological significance. Canadian Journal of Earth Sciences, 5:211-221.

Stover, L.E. 1964. Cretaceous ephedroid pollen from west Africa. Micropaleontology, 10:145-156. doi:10.2307/1484637

Traverse, A. \& Ames, H.T. 1968. Mesozoic and Cenozoic spores, pollen and other microfossils. Pennsylvania, Palynology Laboratories, Pennsylvania State Univiversity, 282 p. (Catalog of Fossil Spores and Pollen 29).

Uliana, M.A. \& Biddle, K.T. 1988. Mesozoic-Cenozoic paleogeographic and geodynamic evolution of southern South America. Revista Brasileira de Geociências, 18:172-190.
Uliana, M.A.; Biddle, K. \& Cerdan, J. 1989. Mesozoic extension and formation, Argentine sedimentary basins. Tulsa, American Association of Petroleum, p. 599-614 (Memoir 46).

Vajda-Santivanez, V. 1999. Miospores from Upper CretaceousPaleocene strata in northwestern Bolivia. Palynology, 23:181196. doi:10.1080/01916122.1999.9989527

Vakrameev, V.A. 1981. Pollen Classopollis: indicator of Jurassic and Cretaceous climates. The Palaeobotanist, 28-29:301-307. doi:10.1080/00206818209451058

Valencio, D.A.; Giudice, A.; Mendía, J.E. \& Oliver, G.J. 1976. Paleomagnetismo y edades K/Ar del Subgrupo Pirgua, provincia de Salta, República Argentina. In: CONGRESO GEOLÓGICO ARGENTINO, 6, 1975. Actas, Bahía Blanca, Universidad Nacional del Sur, p. 527-542.

Vallati, P. 2001. Middle Cretaceous microflora from the Huincul Formation ("Dinosaurian beds") in the Neuquén Basin, Patagonia, Argentina. Palynology, 25:179-197. doi:10.1080/0 1916122.2001.9989559

Villar de Seoane, L. \& Archangelsky, S. 2008. Taxonomy and biostratigraphy of Cretaceous megaspores from Patagonia, Argentina. Cretaceous Research, 29:354-372. doi:10.1016/j. cretres.2007.07.002

Volkheimer, W. 1980. Microfloras del Jurásico Superior y Cretácico Inferior de América Latina. In: CONGRESO ARGENTINO DE PALEONTOLOGÍA Y BIOESTRATIGRAFÍA, 2/ CONGRESO LATINOAMERICANO DE PALEONTOLOGÍA, 1, 1978. Actas, Buenos Aires, p. 121-136.

Volkheimer, W. \& Melendi, D.L. 1976. Palinomorfos como fósiles guía ( $3^{\text {a }}$ parte). Técnicas de laboratorio palinológico. Revista Minera Geología y Mineralogía, 34:19-30.

Volkheimer, W. \& Salas, A. 1976. Estudio palinológico de la Formación Huitrín, Cretácico de la Cuenca Neuquina, en su localidad tipo. In: CONGRESO GEOLÓGICO ARGENTINO, 6, 1975. Actas, Bahía Blanca, Universidad Nacional del Sur, p. 433-456.

Wan, C.B.; Qiao, X.Y.; Wang, R.H. \& \& He, C.Q. 1997. Cretaceous nonmarine microphyplankton from the Hongqi Depression in the Hailar Basin, NE China. Acta Micropalaeontologica Sinica, 14:405-418.

Warny, S.; Jarzen, D.M.; Evans, A.; Hesp, P. \& Philip, B. 2012. Environmental significance if abundant hornwort spores in a potential submerged Paleoindian site in the Gulf of Mexico. Palynology, 36:234-253. doi:10.1080/01916122.2012.666507

Zavattieri, A.M. 1992. Palinología de la Formación El Tranquilo (Triásico) provincia de Santa Cruz, Argentina. Ameghiniana, 29:305-314.

Zavattieri, A.M. \& Prámparo, M.E. 2006. Freshwater algae from the Upper Triassic Cuyana Basin of Argentina: palaeoenvironmental implications. Palaeontology, 49:1185-1209. doi:10.1111/j.14754983.2006.00596.x

Zippi, P.A. 1998. Freshwater algae from the Mattagami Formation (Albian), Ontario: paleoecology, botanical affinities, and systematic taxonomy. Micropaleontology, 44:1-78. doi:10.2307/1485998

Received in May, 2013; accepted in July, 2014. 
Appendix. List of identified species in alphabetic order.

Terrestrial palynomorphs

Alisporites sp. (Figure 4A)

Auritulinasporites sp. (Figure 3A)

Balmeiopsis limbatus (Balme) Archangelsky, 1977 (Figures 4B-C)

Balmeisporites sp. 1 (Figures 3B-C)

Biretisporites sp. (Figure 3D)?

?Ceratosporites sp. (Figure 3E)

Cicatricosisporites cuneiformis Pocock, 1964 (Figure 3F)

Cicatricosisporites sp. 1 (in Narváez et al., 2013) (Figure 3G)?

?Cristatitriletes sp. (Figure $3 \mathrm{H}$ )

Classopollis classoides (Pflug) Pocock \& Jansonius, 1961 (Figure 4D)

Classopollis simplex (Danzé, Corsin \& Laveine) Reiser \& Williams, 1969 (Figure 4E)

Cycadopites sp. (Figure 4F)

Deltoidospora minor (Couper) Pocock, 1970 (Figure 3I)

Dictyophyllidites sp. (Figure 3J)

Ephedripites caichiguensis (Volkheimer \& Quattrocchio) Narváez \& Sabino, 2008 (Figure 4G)

Ephedripites montanaensis Brenner, 1968 (Figure 4L)

Ephedripites ovatus (Pierce) comb. nov. (Figures $4 \mathrm{H}-\mathrm{I}$ )

Fisciniasporites sp. cf. F. brevilaesuratus (Couper) Dettmann \& Clifford, 1992 (Figure 3K)

Fisciniasporites sp. (in Narváez et al., 2013) (Figure 3L)

Gnetaceaepollenites barghoornii (Pocock) Lima, 1980 (Figures 4J-K)

Gnetaceaepollenites jansonii (Pocock) Lima, 1980 (Figures 4M-N)

Leptolepidites sp. (Figure 3M)

?Matonisporites sp. (Figures 3N-O)

Polypodiisporites sp. (Figure 3P)

?Raistrickia sp. (Figure 3Q)

Ruffordiaspora ludbrookiae (Dettmann) Dettmann \& Clifford, 1992 (Figure 3R)

Ruffordiaspora cf. R. ticoensis (Archangelsky \& Gamerro) Archangelsky A.; Archangelsky S.; Poiré \& Canessa, 2008 (Figure 3S)

Ruffordiaspora sp. 1 in Narváez et al., 2013 (Figure 3T)

Steevesipollenites binodosus Stover, 1964 (Figures 4O-P)

Tricolpites variabilis Burger, 1970 (Figures 4Q-R)

Aquatic palynomorphs

Botryococcus sp. (Figures 5A-B)

Leiosphaeridia-type 1 (Figures 5C-D)

Leiosphaeridia-type 2 (Figure 5E)

Echinate vesicle indet. (Figures 5F-G) 